\title{
A Látrányi Puszta Természetvédelmi Terület nagylepke (Lepidoptera) faunájának vizsgálata
}

\author{
ÁBRAHÁM LEVENTE
}

\author{
Somogy County Museum, Natural History Department, \\ H-7400 Kaposvár, Fő u.10., Hungary, e-mail: levi@smmi.hu
}

\begin{abstract}
ÁBRAHÁM L.: Investigation on the butterfly and larger moth fauna of the Látrányi Fuszta Nature Conservation Area (Lepidoptera)

Abstract: Between 1999-2001, the author carried out an investigation of the butterfly and larger moth fauna in the Látrányi Puszta Naturc Conscrvation Area. For the faunistical and nature conservation survey, netting technique was used during the day and at night larger moths were collected by lamp and portable light traps. As a result 451 species were recorded, including 69 butterfly species. 13 protected species can be found in the protected area. Oligia fasciuncula (Haworth, 1809) is new in the Hungarian fauna. The significant species for nature protection are: Maculinea teleius (Bergsträsscr, 1779), Maculinea nausithous (Bergsträsser, 1779), Chariaspilates formosaria (Eversmann, 1837), Diachrysia zosimi (Hübner, 1822), Apamea sicula tallosi Kovács et Varga, 1969, Hadena silenes (Hübner, 1822), Euxoa segnilis (Duponchel, 1836), Setina roscida (Denis \& Schiffermüller, 1775).
\end{abstract}

Key words: Oligia fasciuncula, faunistical evaluation, protected species, Hungary

\section{Bevezetés}

A Látrányi Puszta Természetvédelmi Terület rovarfaunája az 1999-ben megkezdődött természetvédelmi felmérés kezdetéig gyakorlatilag ismeretlen volt. Sem az entomológiai szakirodalomban, sem a természettudományi múzeumi gyüjteményekben nem voltak értékelhető adatok a területről.

Az első, természetvédelmi szempontból is hasznositható információ az 1991-1994 között "Somogy természeti értékei" címü OTKA kutatási téma (SMM Természettudományi Osztálya) keretében született a veszélyeztetett Maculinea nausithous és a Maculinea teleius populáció becsléséröl. E munka során figyeltem fel a területen élő védett Lycaena alciphron-ra is, amelynek a Dunántúli-dombságon az egyetlen ismert populációja itt található.

A természetvédelmi terület zoológiai alapállapot felmérése 2001-ben is szükségessé vált, mivel nem rendelkeztünk természetvédelmi szempontból értékelhető adattal. A védett terület tágabb környezetében csak a Boronka-melléki Tájvédelmi Körzetben volt rendszeres természetvédelmi célú kutatás (ÁBRAHÁM 1992). Ugyanakkor ez a homokvidék több szempontból jelentősen el is tér attól. Az OTKA-kutatások keretében megállapítást nyert, hogy a Látrányi Puszta Természetvédelmi Terület homok felhalmozódásai harmad- és negyedidőszakiak. A Negyedidőszakban a Balaton egykori öblözetének lerakódásaiból származik a szél által áthalmozott homok. A homok kémhatása is eltér a belső-somogyi savanyú homoktól, ugyanis itt a homokpusztán elsődlegesen meszes homok adja az alapkőzetet, ami általában megmutatkozik a növényzeten keresztül az elsődleges fogyasztó nagylepke fauna színező elemeiben is (VARGA 1964). 
A Látrányi Puszta Természetvédelmi Terület földrajzi elhelyezkedését tekintve zoogeográfiai szempontból is rendkívül érdekes helyen fekszik. Az Illyricum és a Bakonyicum határövezetében található és már az elözetes terepbejárások alkalmával gyüjtött megfigyelésekböl feltételezhető volt, hogy faunája átmeneti jellegü.

A természetvédelmi vizsgálatok célja, hogy a terület faunájáról elkészítsük az első faunalistát, felderitsük a védett, veszélyeztetett fajok populációit és az összegyüjtött információk alapján elösegítsük a kezelési terv elkészítését.

\section{Anyag és módszer}

A nagylepkefauna felmérésének módszerét elsősorban a vizsgálat célkitüzése határozta meg, ezért arra törekedtem, hogy a vizsgálati területen minél több élöhelyröl gyüjtsek mintákat. Ehhez a terep bejárása után állandó, a területre jellemző mintavételi helyeket jelöltem ki (1. ábra), amelyeket gyüjtés céljából rendszeresen látogattam.

A faunafelmérés során a nappali lepkék esetében különös figyelmet fordítottam a védett fajok tápnövényeinek felkutatására.

Az éjszakai lepkéknél többféle módszer együttes alkalmazásával gyüjtöttem mintákat, ehhez a személyes lámpázásokkor $160 \mathrm{~W}$-os HGLI izzót és $20 \mathrm{~W}$-os ún. fekete fényü (black light) UV elektroncsövet használtam.

Emellett a jellegzetes élőhelyfoltokban hordozható, akkumulátorról üzemelö, $8 \mathrm{~W}$-os, szintén fekete fényü (black light) UV elektroncsövekkel felszerelt fénycsapdákat állítottam fel, egy mintavétel alkalmával egyszerre $4 \mathrm{db}$-ot.

$\mathrm{Az}$ őszi és tavaszi hónapokban még a csalétken is gyüjtőttem.

A mintavételezések 1999-ben és 2001-ben is a vegetációs időszak egészére kiterjedtek.

\section{Eredmények}

A Látrányi Puszta Természetvédelmi Terület entomológiai vizsgálata során a nagylepke faunából 451 faj vált ismertté. Ebböl a nappali lepkefajok száma 69. A védett terület nagylepkéinek faunalistáját KARSHOLT és RAZOWSKI (1996) munkája nyomán állítottam össze, ezt a nevezéktant használtuk (ÁBRAHÁM és UHERKOVICH 2001) Somogy fauna katalógusában a nagylepkékröl publikált, összefoglaló jellegü cikk összeállításakor is.

\section{A fajok listája}

Hepialidae

Hepialis humuli (Linnacus, 1758)

Triodia sylvina (Linnacus, 1761)

Cossidae

Dyspessa ulula (Borkhauscn, 1790)

Zeuzera pyrina (Linnacus, 1761)

Phragmatoecia casteneae (Hübncr, 1790)

Limacodidae

Apoda limacodes (Hufnagel, 1766)

\section{Lasiocampidae}

Malacosoma castrensis (Linnacus, 1758)

Lasiocampa trifolii (Dcnis \& Schiffcrmüller, 1775)

Lasiocampa quercus (Linnacus, 1758)

Macrothylacia rubi (Linnacus, 1758)

Dendrolimus pini (Linnacus, 1758)

Euthrix potatoria (Linnaeus, 1758)

Gastropacha quercifolia (Linnacus, 1758)

Gastropacha populifolia (Denis \&

Schiffermüller, 1775)

Odonestis pruni (Linnacus, 1758) 


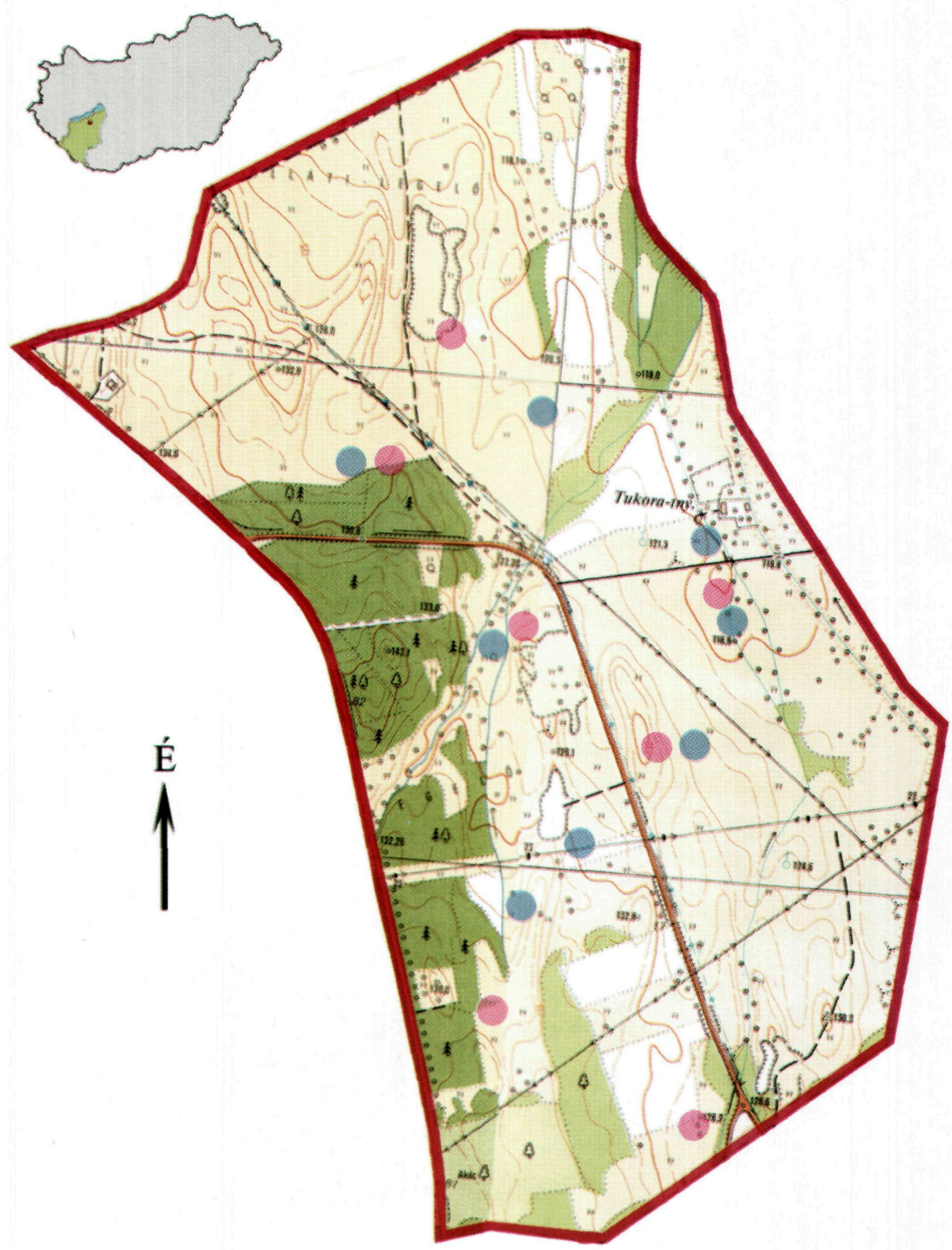




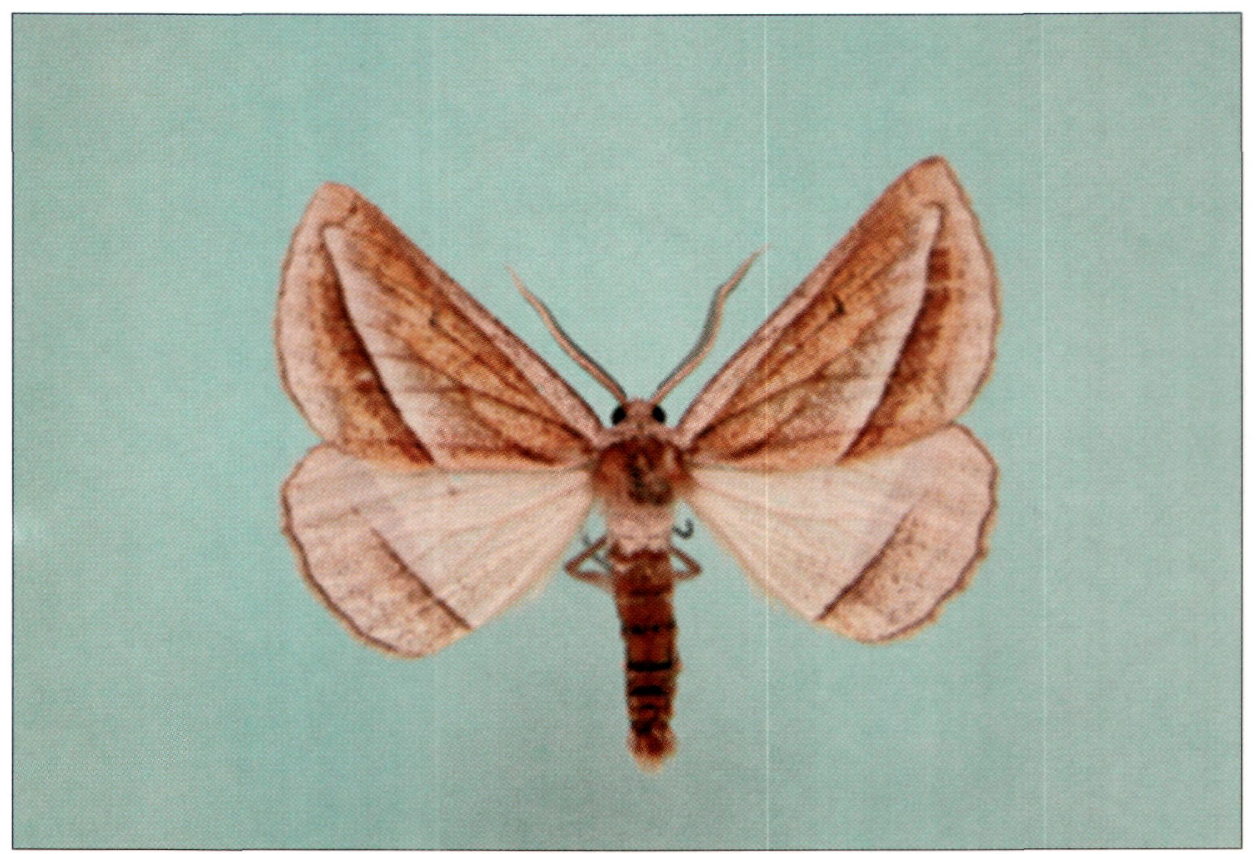

3. ábra: A védett Chariaspilates formosaria (Eversmann, 1837)

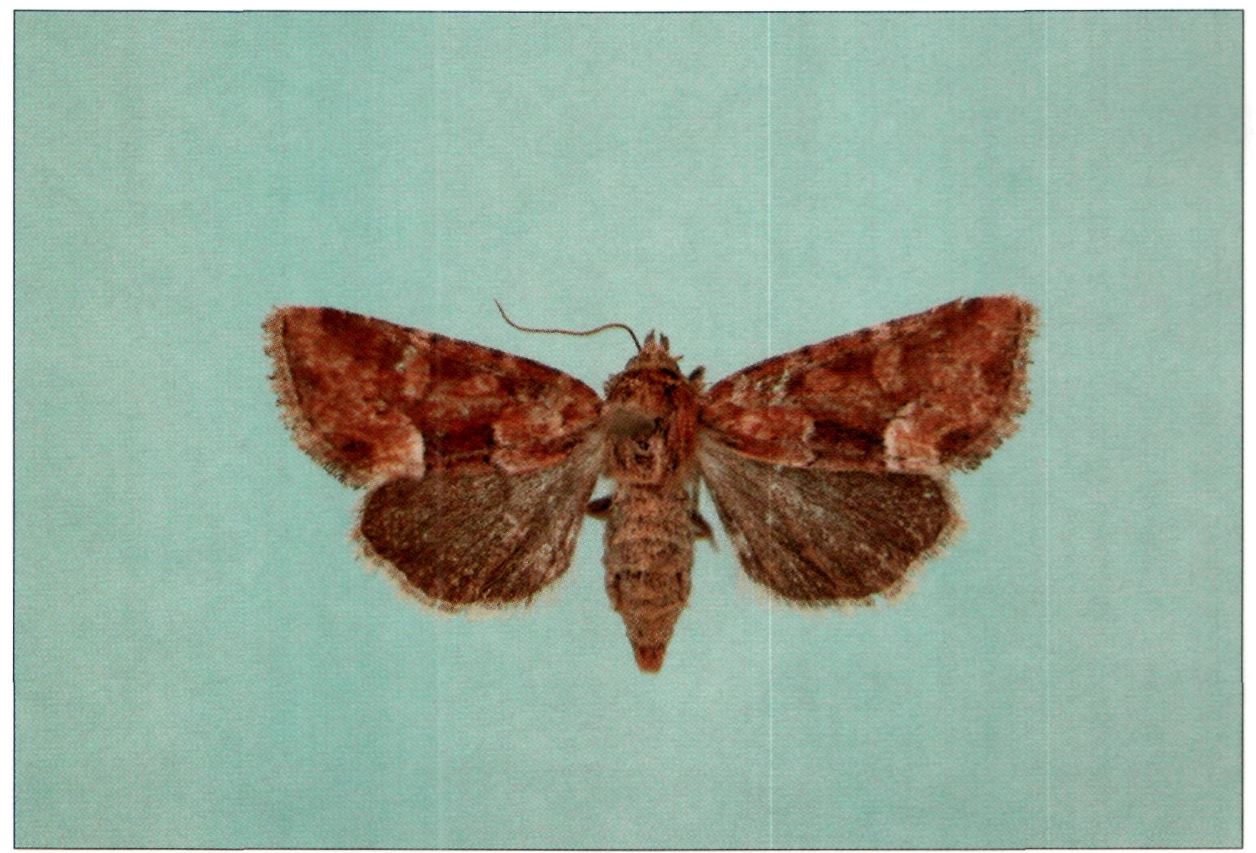

4. ábra: Oligia fasciuncula (Haworth, 1809) a hazai bagolylepke fauna új tagja 
Sphingidae

Mimas tiliae (Linnaeus, 1758)

Smerinthus ocellata (Linnaeus, 1758)

Agrius convolvuli (Linnaeus, 1758)

Sphinx ligustri Linnaeus, 1758

Hyloicus pinastri (Linnaeus, 1758)

Macroglossum stellatarum (Linnaeus, 1758)

Hyles euphorbiae (Linnaeus, 1758)

Deilephila elpenor (Linnaeus, 1758)

Deilephila porcellus (Linnaeus, 1758)

\section{Hesperiidae}

Erynnis tages (Linnacus, 1758)

Carcharodus alceae (Esper, 1780)

Pyrgus carthami (Hübner, 1813)

Pyrgus malvae (Linnaeus, 1758)

Heteropterus morpheus (Pallas, 1771)

Thymelicus sylvestris (Poda, 1761)

Ochlodes venata (Bremer \& Grey, 1853)

\section{Papilionidae}

Iphiclides podalirius (Linnacus, 1758)

Papilio machaon Linnacus, 1758

\section{Pieridae}

Leptidea sinapis (Linnaeus, 1758)

Leptidea reali Reissinger, 1989

Anthocharis cardamines (Linnaeus, 1758)

Pieris brassicae (Linnacus, 1758)

Pieris rapae (Linnacus, 1758)

Pieris napi (Linnaeus, 1758)

Pontia daplidice (Linnacus, 1758)

Colias croceus (Fourcroy, 1785)

Colias hyale (Linnacus, 1758)

Colias alfacariensis Ribbe, 1905

Gonepteryx rhamni (Linnacus, 1758)

\section{Lycaenidae}

Hamearis lucina (Linnacus, 1758)

Lycaena phlaeas (Linnaeus, 1761)

Lycaena dispar (Haworth, 1802)

Lycaena tityrus (Poda, 1761)

Lycaena alciphron (Rottemburg, 1775)

Callophrys rubi (Linnaeus, 1758)

Satyrium acaciae (Fabricius, 1787)

Cupido argiades (Pallas, 1771)

Cupido alcetas (Hoffmannsegg, 1804)

Celastrina argiolus (Linnacus, 1758)

Scolitantides orion (Pallas, 1771)

Glaucopsyche alexis (Poda, 1761)

Maculinea teleius (Bergsträsser, 1779)

Maculinea nausithous (Bergsträsser, 1779)

Plebeius argus (Linnacus, 1758)

Plebeius argyrognomon (Bergsträsser, 1779)

Aricia agestis (Denis \& Schiffermüller, 1775)

Polyommatus icarus (Rottemburg, 1775)

Nymphalidae

Agynnis paphia (Linnacus, 1758)
Argynnis adippe (Denis \& Schiffermüller, 1775)

Issoria lathonia (Linnacus, 1758)

Brenthis daphne (Denis \& Schiffermüller, 1775)

Boloria dia (Linnaeus, 1767)

Boloria selene (Denis \& Schiffermüller, 1775)

Vanessa atalanta (Linnaeus, 1758)

Vanessa cardui (Linnaeus, 1758)

Inachis io (Linnaeus, 1758)

Polygonia c-album (Linnaeus, 1758)

Araschnia levana (Linnacus, 1758)

Euphydryas aurinia (Rottemburg, 1775)

Melitaea cinxia (Linnaeus, 1758)

Melitaea phoebe (Denis \& Schiffermüller, 1775)

Melitaea aurelia Nickerl, 1850

Melitaea athalia (Rottemburg, 1775)

Neptis sappho (Pallas, 1771)

Apatura ilia (Denis \& Schiffermüller, 1775)

Pararge aegeria (Linnacus, 1758)

Lasiommata megera (Linnacus, 1767)

Lasiommata maera (Linnaeus, 1758)

Coenonympha arcania (Linnacus, 1761)

Coenonympha glycerion (Borkhausen, 1788)

Coenonympha pamphilus (Linnaeus, 17581

Aphantopus hyperantus (Linnaeus, 1758)

Maniola jurtina (Linnacus, 1758)

Melanargia galathea (Linnacus, 1758)

Minois dryas (Scopoli, 1763)

Arethusana arethusa (Denis \& Schiffermüller, 1775)

Brintesia circe (Fabricius, 1775)

\section{Drepanidae}

Thyatira batis (Linnacus, 1758)

Habrosyne pyritoides (Hufnagel, 1766)

Tethea ocularis (Linnaeus, 1767)

Tethea or (Denis \& Schiffermüller, 1775)

Ochropacha duplaris (Linnacus, 1761)

Cymatophorima diluta (Denis \& Schiffermüller, 1775)

Watsonalla binaria (Hufnagel, 1767)

Drepana curvatula (Borkhausen, 1790)

Drepana falcataria (Linnacus, 1758)

Sabra harpagula (Esper, 1786)

Cilix glaucata (Scopoli, 1763)

\section{Geometridae}

Abraxas grossulariata (Linnacus, 1758)

Lomaspilis marginata (Linnacus, 1758)

Ligdia adustata (Denis \& Schiffermüller, 1775)

Heliomata glarearia (Denis \& Schiffcrmüller, 1775)

Macaria alternata (Denis \& Schiffermüller, 1775)

Macaria liturata (Clerck, 1759)

Tephrina arenacearia (Denis \& Schiffermüller, 1775)

Chiasmia clathrata (Linnacus, 1758)

Plagodis dolabraria (Linnacus, 1767)

Epione repandaria (Hufnagel, 1767)

Pseudopanthera macularia (Linnacus, 1758)

Hypoxystis pluviaria (Fabricius, 1787)

Selenia dentaria (Fabricius, 1775)

Selenia lunularia (Hübncr, 1788)

Selenia tetralunaria (Hufnagel, 1767) 
Crocallis elinguaria (Linnacus, 1758)

Angerona prunaria (Linnacus, 1758)

Biston betularia (Linnaeus, 1758)

Synopsia sociaria (Hübner, 1799)

Peribatodes rhomboidaria (Denis \&

Schiffcrmüller, 1775)

Hypomecis roboraria (Denis \& Schiffermüller, 1775)

Hypomecis punctinalis (Scopoli, 1763)

Hypomecis danieli (Wchrli, 1932)

Ascotis selenaria (Denis \& Schiffermüller, 1775)

Ectropis crepuscularia (Denis \& Schiffermüller, 1775)

Ematurga atomaria (Linnacus, 1758)

Bupalus piniaria (Linnacus, 1758)

Cabera pusaria (Linnaeus, 1758)

Cabera exanthemata (Scopoli, 1763)

Lomographa bimaculata (Fabricius, 1775)

Lomographa temerata (Denis \& Schiffermüller, 1775)

Campaea margaritata (Linnacus, 1767)

Hylaea fasciaria (Linnacus, 1758)

Siona lineata (Scopoli, 1763)

Chariaspilates formosaria (Eversmann, 1837)

Aspitates gilvaria (Denis \& Schiffermüller, 1775)

Geometra papilionaria (Linnacus, 1758)

Comibaena bajularia (Denis \& Schiffermüller 1775)

Hemithea aestivaria (Hübner, 1789)

Chlorissa viridata (Linnaeus, 1758)

Chlorissa cloraria (Hübncr, 1813)

Thalera fimbrialis (Scopoli, 1763)

Jodis lactearia (Linnacus, 1758)

Cyclophora pendularia (Clcrck, 1759)

Cyclophora annularia (Fabricius, 1775)

Cyclophora porata (Linnaeus, 1767)

Cyclophora quercomontaria (Bastelberger, 1897)

Cyclophora punctaria (Linnacus, 1758)

Timandra comae A Schmidt, 1931

Scopula immorata (Linnacus, 1758)

Scopula caricaria (Reutti, 1853)

Scopula nigropunctata (Hufnagel, 1767)

Scopula virgulata (Denis \& Schiffermüller, 1775)

Scopula rubiginata (Hufnagel, 1767)

Scopula incanata (Linnacus, 1758)

Idaea ochrata (Scopoli, 1763)

Idaea muricata (Hufnagel, 1767)

Idaea rusticata (Denis \& Schiffermüller, 1775)

Idaea biselata (Hufnagel, 1767)

Idaea inquniata (Scopoli, 1763)

Idaea fuscovenosa (Goczc, 1781)

Idaea politaria (Hübncr, 1799)

Idaea subsericeata (Haworth, 1809)

ldaea aversata (Linnacus, 1758)

Idaea degeneraria (Hübncr, 1799)

Rhodostrophia vibicaria (Clcrck, 1759)

Phibalapteryx virgata (Hufnagel, 1767)

Xanthorhoe spadicearia (Denis \&

Schiffcrmüller, 1775)

Xanthorhoe ferrugata (Clerck, 1759)

Catarhoe cuculata (Hufnagel, 1767)

Epirrhoe pupillata (Thunbcrg, 1788)

Epirrhoe tristata (Linnacus, 1758)
Epirrhoe galiata (Denis \& Schiffermüller, 1775)

Costaconvexa polygrammata (Borkhausen, 1794

Camptogramma bilineata (Linnacus, 1758)

Anticlea badiata (Denis \& Schiffermüller, 1775)

Pelurga comitata (Linnacus, 1758)

Cosmorhoe ocellata (Linnacus, 1758)

Eulithis mellinata (Fabricius, 1787)

Thera obeliscata (Hübner, 1787)

Colostygia pectinataria (Knoch, 1781)

Hydriomena impluviata (Denis \&

Schiffermüller, 1775)

Philereme vetulata (Denis \& Schiffermüller, 1775)

Philereme transversata (Hufnagel, 1767)

Euphyia unangulata (Haworth, 1809)

Perizoma alchemillata (Linnacus, 1758)

Perizoma flavofasciata (Thunberg, 1792)

Eupithecia haworthiata Doubleday, 1856

Eupithecia absinthiata (Clerck, 1759)

Eupithecia assimilata Doubleday, 1856

Eupithecia vulgata (Haworth, 1809)

Eupithecia tripunctaria Herrich-Schäffer, 1852

Eupithecia subfuscata (Haworth, 1809)

Eupithecia icterata (Villers, 1789)

Eupithecia succenturiata (Linnacus, 1758)

Eupithecia innotata (Hufnagel, 1767)

Eupithecia virgaureata Doubleday, 1861

Chloroclystis v-ata (Haworth, 1809)

Rhinoprora rectangulata (Linnaeus, 1758)

Anticollix sparsata (Treitschke, 1828)

Aplocera efformata (Guenćc, 1857)

Euchoeca nebulata (Scopoli, 1763)

Asthena anseraria (Herrich-Schäffer, 1855)

Hydrelia flammeolaria (Hufnagcl, 1767)

Minoa murinata (Scopoli, 1763)

Trichopteryx carpinata (Borkhausen, 1794)

Pterapherapteryx sexalata (Rctzius, 1783)

\section{Notodontidae}

Clostera curtula (Linnacus, 1758)

Clostera pigra (Hufnagel, 1766)

Clostera anastomosis (Linnaeus, 1758)

Cerura erminea (Esper, 1783)

Furcula furcula (Clcrck, 1759)

Furcula bifida (Brahm, 1787)

Notodonta dromedarius (Linnacus, 1758)

Notodonta tritophus (Denis \& Schiffcrmüller, 1775)

Notodonta ziczac (Linnacus, 1758)

Drymonia querna (Denis \& Schiffermüller, 1775)

Diymonia velitaris (Hufnagcl, 1766)

Pterostoma palpina (Clcrck, 1759)

Ptilodon capucina (Linnaeus, 1758)

Ptilodon cucullina (Denis \& Schiffermüller, 1775)

Gluphisia crenata (Esper, 1785)

Stauropus fagi (Linnaeus, 1758)

Spatalia argentina (Denis \& Schiffermüller, 1775)

\section{Noctuidae}

Acronicta alni (Linnacus, 1767)

Acronicta cuspis (Hübncr, 1813) 
Acronicta aceris (Linnacus, 1758)

Acronicta leporina (Linnacus, 1758)

Acronicta megacephala (Denis \&

Schiffermüller, 1775)

Acronicta auricoma (Denis \& Schiff'crmüller, 1775)

Acronicta rumicis (Linnaeus, 1758)

Craniophora ligustri (Denis \& Schiffermüller, 1775)

Simyra nervosa (Denis \& Schiffermüller, 1775)

Simyra albovenosa (Gocze, 1781)

Cryphia algae (Fabricius, 1775)

Simplicia rectalis (Eversmann, 1842)

Paracolax tristalis (Fabricius, 1794)

Macrochilo cribrumalis (Hübner, 1793)

Herminia tarsicrinalis (Knoch, 1782)

Herminia grisealis (Denis \& Schiffermüller, 1775)

Polypogon tentacularia (Linnacus, 1758)

Polypogon gryphalis (Herrich-Schäffer, 1851)

Zanclognatha tarsipennalis Treitschke, 1835

Catocala nupta (Linnacus, 1767)

Catocala elocata (Esper, 1787)

Catocala hymenaea (Denis \& Schiffermüller, 1775)

Catocala fulminea (Scopoli, 1763)

Lygephila lusoria (Linnacus, 1758)

Lygephila pastimum (Trcitschkc, 1826)

Lygephila craccae (Denis \& Schiffermüller, 1775)

Lygephila viciae (Hübncr /1819-1822/)

Tyta luctuosa (Denis \& Schiffermüller, 1775)

Euclidia glyphica (Linnacus, 1758)

Laspeyria flexula (Denis \& Schiffermüller, 1775)

Scoliopteryx libatrix (Linnaeus, 1758)

Calyptra thalictri (Borkhausen, 1790)

Hypena proboscidalis (Linnacus, 1758)

Hypena rostralis (Linnacus, 1758)

Phytometra viridaria (Clerck, 1759)

Rivula sericealis (Scopoli, 1763)

Colobochyla salicalis (Denis \& Schiffermüller, 1775)

Diachrysia chrysitis (Linnaeus, 1758)

Diachrysia zosimi (Hübner, 1822)

Diachrysia chryson (Esper, 1789)

Macdunnoughia confusa (Stephens, 1850)

Plusia festucae (Linnacus, 1758)

Autographa gamma (Linnacus, 1758)

Abrostola tripartita (Hufnagel, 1766)

Abrostola asclepiadis (Denis \& Schiffermüller, 1775)

Abrostola triplasia (Linnacus, 1758)

Emmelia trabealis (Scopoli, 1763)

Protodeltote pygarga (Hufnagel, 1766)

Deltote uncula (Clerck, 1759)

Deltote bankiana (Fabricius, 1775)

Pseudeustrotia candidula (Denis \&

Schiffermüllcr, 1775)

Eublemma minutata (Fabricius, 1794)

Eublemma puppurina (Denis \& Schiffermüller, 1775)

Trisateles emortualis (Denis \& Schiffcrmüller, 1775)

Cucullia umbratica (Linnacus, 1758)

Amphipyra pyramidea (Linnaeus, 1758)

Amphipyra livida (Denis \& Schiffermüller, 1775)

Amphipyra tragopoginis (Clerck, 1759)

Heliothis viriplaca (Hufnagel, 1766)
Heliothis peltigera (Denis \& Schiffermüller, 1775)

Pyrrhia umbra (Hufnagel, 1766)

Elaphria venustula (Hübner, 1790)

Acosmetia caliginosa (Hübner, 1813)

Caradrina morpheus (Hufnagel, 1766)

Platyperigea kadenii (Freyer, 1836)

Hoplodrina respersa (Denis \& Schiffermüller, 1775)

Hoplodrina ambigua (Denis \& Schiffermüller, 1775)

Charanyca trigrammica (Hufnagel, 1766)

Atypha pulmonaris (Esper, 1790)

Athetis pallustris (Hübner, 1808)

Proxenus lepigone (Möschler, 1860)

Dypterygia scabriuscula (Linnaeus, 1758)

Rusina ferruginea (Esper, 1785)

Polyphaenis sericata (Esper, 1787)

Thalpophila matura (Hufnagel, 1766)

Trachea atriplicis (Linnaeus, 1758)

Euplexia lucipara (Linnacus, 1758)

Phlogophora meticulosa (Linnaeus, 1758)

Actinotia polyodon (Clerck, 1759)

Eucarta amethystina (Hübner, 1803)

Eucarta virgo (Treitschke, 1835)

Ipimorpha retusa (Linnacus, 1761)

Parastichtis ypsillon (Denis \& Schiffermüller, 1775)

Mesogona oxalina (Hübner, 1803)

Cosmia affinis (Linnacus, 1767)

Cosmia trapezina (Linnaeus, 1758)

Xanthia aurago (Denis \& Schiffermüller, 1775)

Xanthia sulphurago (Denis \& Schiffermüller, 1775)

Xanthia icteritia (Hufnagel, 1766)

Xanthia citrago (Linnacus, 1758)

Agrochola circellaris (Hufnagel, 1766)

Agrochola lota (Clcrck, 1759)

Agrochola nitida (Denis \& Schiffermüller, 1775)

Agrochola helvola (Linnaeus, 1758)

Conistra vaccinii (Linnaeus, 1761)

Episema glaucina (Esper, 1789)

Episema tersa (Denis \& Schiffermüller, 1775)

Brachylomia viminalis (Fabricius, 1776)

Aporophyla lutulenta (Denis \& Schiffermüller, 1775)

Meganephria bimaculosa (Linnaeus, 1767)

Allophyes oxyacanthae (Linnacus, 1758)

Valeria oleagina (Denis \& Schiffermüller, 1775)

Ammoconia caecimacula (Denis \&

Schiffermüller, 1775)

Blepharita satura (Denis \& Schiffermüller, 1775)

Apamea monoglypha (Hufnagel, 1766)

Apamea sicula tallosi Kovács et Varga, 1969

Apamea sublustris (Esper, 1788)

Apamea remissa (Hübncr, 1809)

Apamea sordens (Hufnagel, 1766)

Apamea scolopacina (Esper, 1788)

Oligia strigilis (Linnacus, 1758)

Oligia latruncula (Denis \& Schiffermüller, 1775)

Oligia fasciuncula (Haworth, 1809)

Mesapamea secalis (Linnaeus, 1758)

Photedes minima (Haworth, 1809)

Hydraecia micacea (Esper, 1789)

Gortyna flavago (Denis \& Schiffermüller, 1775) 
Calamia tridens (Hufnagel, 1766)

Celaena leucostigma (Hübner, 1808)

Archanara dissoluta (Treitschke, 1825)

Archanara sparganii (Esper, 1790)

Chortodes extrema (Hübncr, 1809)

Sedina buettneri (E Hering, 1858)

Lacanobia w-latinum (Hufnagel, 1766)

Lacanobia oleracea (Linnaeus, 1758)

Lacanobia contigua (Denis \& Schiffermüller, 1775)

Lacanobia suasa (Denis \& Schiffermüller, 1775)

Hada plebeja (Linnacus, 1761)

Hadena perplexa (Denis \& Schiffermüller, 1775)

Hadena silenes (Hübner, 1822)

Hadena irregularis (Hufnagel, 1766)

Heliophobus reticulata (Gocze, 1781)

Melanchra persicariae (Linnacus, 1761)

Melanchra pisi (Linnaeus, 1758)

Mamestra brassicae (Linnaeus, 1758)

Polia nebulosa (Hufnagel, 1766)

Mythimna turca (Linnaeus, 1761)

Mythimna conigera (Denis \& Schiffermüller, 1775)

Mythimna ferrago (Fabricius, 1787)

Mythimna albipuncta (Denis \& Schiffcrmüller, 1775)

Mythimna vitellina (Hübner, 1808)

Mythimna pudorina (Denis \& Schiffermüller, 1775)

Mythimna impura (Hübner 1808

Mythimna pallens (Linnacus, 1758)

Mythimna obsoleta (Hübner, 1803)

Mythimna flammea (Curtis, 1828)

Mythimna l-album (Linnacus, 1767)

Orthosia incerta (Hufnagel, 1766)

Orthosia gothica (Linnaeus, 1758)

Orthosia cruda (Denis \& Schiffermüller, 1775)

Orthosia cerasi (Fabricius, 1775)

Panolis flammea (Denis \& Schiffermüller, 1775)

Tholera cespitis (Dcnis \& Schiffermüller, 1775)

Tholera decimalis (Poda, 1761)

Axylia putris (Linnacus, 1761)

Ochropleura plecta (Linnacus, 1761)

Diarsia rubi (Vicweg, 1790)

Noctua pronuba Linnacus, 1758

Noctua interposita (Hübner, 1790)

Noctua comes Hübncr, 1813

Noctua fimbriata (Schrcber, 1759)

Noctua janthina (Denis \& Schiffermüller, 1775)

Noctua janthe (Borkhausen, 1792)

Opigena polygona (Denis \& Schiffermüller, 1775)

Eugnorisma depuncta (Linnacus, 1761)

Xestia c-nigrum (Linnaeus, 1758)

Xestia triangulum (Hufnagcl, 1766)

Xestia baja (Denis \& Schiffermüller, 1775)

Xestia rhomboidea (Espcr, 1790)

Xestia xanthographa (Denis \& Schiffermüller, 1775)

Cerastis rubricosa (Denis \& Schiffermüller, 1775)

Naenia typica (Linnacus, 1758)

Euxoa aquilina (Denis \& Schiffermüller, 1775)
Euxoa segnilis (Duponchel, 1836)

Euxoa tritici (Linnacus, 1761)

Agrotis ipsilon (Hufnagel, 1766)

Agrotis exclamationis (Linnaeus, 1758)

Agrotis segetum (Denis \& Schiffermüller, 1775)

Agrotis vestigialis (Hufnagel, 1766)

Pantheidae

Colocasia coryli (Linnacus, 1758)

\section{Lymantriidae}

Lymantria monacha (Linnaeus, 1758)

Lymantria dispar (Linnacus, 1758)

Orgyia antiqua (Linnacus, 1758)

Penthophera morio (Linnacus, 1767)

Laelia coenosa (Hübner, 1808)

Arctornis l-nigrum (Müller, 1764)

\section{Nolidae}

Meganola gigantula (Staudinger, 1879)

Meganola albula (Denis \& Schiffermüller, 1775)

Nola cucullatella (Linnacus, 1758)

Nola cristatula (Hübncr, 1793)

Nola chlamitulalis (Hübner, 1813)

Nycteola revayana (Scopoli, 1772)

Nycteola asiatica (Krulikovsky, 1904)

Bena bicolorana (Fucssly, 1775)

Pseudoips prasinana (Linnaeus, 1758)

Earias clorana (Linnacus, 1761)

Earias vernana (Fabricius, 1787)

\section{Arctiidae}

Thumatha senex (Hübner, 1808)

Miltochrista miniata (Forster, 1771)

Cybosia mesomella (Linnacus, 1758)

Lithosia quadra (Linnaeus, 1758)

Eilema depressa (Esper, 1787)

Eilema griseola (Hübncr, 1803)

Eilema lurideola (Zincken, 1817)

Eilema complana (Linnacus, 1758)

Eilema pygmaeola (Doubleday, 1847)

Eilema lutarella (Linnacus, 1758)

Eilema sororcula (Hufnagel, 1766)

Setina roscida (Dcnis \& Schiffermüller, 1775)

Amata phegea (Linnacus, 1758)

Dysauxes ancilla (Linnacus, 1767)

Spiris striata (Linnaeus, 1758)

Phragmatobia fuliginosa (Linnacus, 1758)

Spilosoma lutea (Hufnagel, 1766)

Spilosoma lubricipeda (Linnacus, 1758)

Spilosoma urticae (Espcr, 1789)

Hyphantria cunea (Drury, 1773)

Rhyparia purpurata (Linnacus, 1758)

Diacrisia sannio (Linnacus, 1758)

Arctia villica (Linnacus, 1758)

Euplagia quadripunctaria (Poda, 1761) 
Természetvédelmi szempontból figyelemre méltó fajok és azok élöhelyeinek értékelése

A védett fajok száma a hazai gerinctelen állatfauna fajszámának csupán töredékét teszi ki. A szomszédos országokban, e tekintetben messzemenően jobb a helyzet (pl.: Ausztria, Szlovénia, Szlovákia stb.), ezért a természetvédelmi szempontból figyelemre méltó fajok fogalomkörébe a hazai vörös könyves, monitorozandó és az ún. ritka fajokat is besoroltuk, amelyek potenciálisan fontos szerepet kell hogy kapjanak a természetvédelmi intézkedések megalapozásákor.

Az elvégzett faunafelmérés során 11 védett faj, 7 vörös könyves (VARGA 1990) és 4 monitorozandó faj (RONKAY 1997) került elő (1. táblázat). Ezeknél a fajoknál az egyes kategóriák részben átfedik egymást.

1 táblázat: Természetvédelmi szempontból figyelemre méltó fajok a Látrányi Puszta Természetvédelmi Területen

\begin{tabular}{|c|c|c|c|}
\hline Fajnév & $\begin{array}{c}\text { Védett faj, eszmei } \\
\text { értéke (Ft) }\end{array}$ & $\begin{array}{c}\text { Vörös könyves } \\
\text { faj }\end{array}$ & $\begin{array}{c}\mathrm{NBmR} \\
\text { monitorozandó faj }\end{array}$ \\
\hline Apamea sicula syriaca & 2000 & PV & $x$ \\
\hline Chariaspilates formosarius & 10000 & PV & \\
\hline Papilio machaon & 2000 & & \\
\hline Iphiclides podalirius & 10000 & & 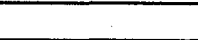 \\
\hline Lycaena dispar & 50000 & & $\mathrm{x}$ \\
\hline Lycaena alciphron & 2000 & & \\
\hline Maculinea nausithous & 50000 & AV & $x$ \\
\hline Maculinea teleius & 50000 & PV & $\mathrm{x}$ \\
\hline Apalura ilia & 2000 & PV & \\
\hline Neptis sappho & 1000 & PV & \\
\hline Vanessa atalanta & 2000 & & \\
\hline Euphydryas aurinia & 50000 & AV & $\mathrm{x}$ \\
\hline Inachis io & 2000 & & \\
\hline
\end{tabular}

Az 1. táblázatban feltüntetett fajok közül az Inachis io és a Vanessa atalanta populációit sem helyi, sem országos szinten nem veszélyeztettek, ezért e fajok természetvédelmi vonatkozásban különleges figyelmet itt a Látrány Puszta Természetvédelmi Területen sem érdemelnek.

Az Apamea sicula tallosi-nak a hazai taxonómiai helyzetének tisztázása (KovÁcs és VARGA 1969) nem olyan régmúltra tekint vissza. Kutatási tapasztalataim szerint e fajnak hazánkban két jellegzetes élöhelye van, tenyészését mindkét élőhelyen elsősorban a nedvességviszonyok befolyásolhatják. Néha tömegesen fordul elö a középhegyvidéki Calamagrostis-os irtásréteken (ÁBRAHÁM és UHERKOVICH 1986), a másik jellemző élőhelye az alacsonyabb domb- és síkvidékek esetében a mocsár- és láprétek, galériaerdök szegélye. A Látrányi Puszta Természetvédelmi Területen ez utóbbi élőhelyeken fordul elö. Hasonló tenyésző helyei vannak a Beregi-síkon (Lónya), a Dráva-síkon (Kisdobsza) és a Kis-Balatonon (RoNKAY 1997). A területröl elökerült példányok a Visz község környéki erdök (bükkös, gyertyános-tölgyes és ezek irtásai) magaskóros élöhelyeiről is származhatnak még, mert a védett terület tágabb környezetében az élöhelyek légvonalban közel vannak..

A Chariaspilates formosarius diszjunkt elterjedésü faj, a Kárpát-medencében önálló alfaja él (VoJNITs 1977). Magyarországon népesebb populációját csak lápvidékekről, Orgoványból és Bátorligetről ismertük. A Duna-Dráva NP Igazgatóság felügyeleti területén csak három helyről sikerült kimutatni: Baláta-tó, Kisberény, Látrányi Puszta 
Természetvédelmi Terület. Ezek közül a Látrányban talált populációja tünik a legnépesebbnek. Az önálló taxont képező faj élőhelyeinek mindegyike a területi védettség ellenére veszélyeztetett, ezért a most talált populáció nagy természetvédelmi jelentőséggel bír. Itt a faj élőhelye a magassásos lápréteken található. Évente egy nemzedéke fejlődik ki. Hernyójának tápnövénye a Lysimachia vulgaris vagy a Caltha palustris lehet.

A Papilio machaon és a Iphiclides podalirius a pillangók családjába tartozó védett fajok. Hernyóik tenyészöhelye a homokhátak szegélyén található. A kifejlett imágók a homokbuckákon növő virágokon táplálkoznak. Populációikra a védett területbe ékelödő szántóföldek növényvédelmi célú vegyszerezése jelenthet veszélyforrást.

A Lycaena dispar hazai populációi még stabilnak tünnek, így valószínüleg a látrányi is az, de a nyugat-európai kedvezőtlen példák azt mutatják, hogy a faj erösen sérülékeny. Nagy-Britanniából már kipusztult, Németországból és a Benelux országokból is szinte eltünt. A faj populációnagyságának állandó figyelemmel tartása a védett területen mindenképpen indokolt. A 2003-ban megkezdett Nemzeti Biomonitorozó Rendszer keretében elvégzett felmérések, és információ gyüjtések adhatnak majd választ a faj hazai populáció szintü természetvédelmi értékelésére. Élőhelye a védett területen, a lápréteken található.

A Lycaena alciphron védett, ritka boglárkalepkék egyike. A Látrányi Puszta Természetvédelmi Területen kívül jelenleg egyetlen populációja sem ismert a Dunántúli-dombságról. Somogyból azonban a múlt század elejéröl ebből a körzetből is volt adata, de a populáció pontos lokalitása nem volt beazonosítható (ABAFI-AIGNER et al. 1899). A faj jellegzetes elöfordulási helyei középhegyvidéki cserjékkel benőtt dolomitrétek, és bokorerdő szegélyek (DiETzEL 1997). Az Alfödön hasonló jellegü homokpusztákon tenyészik, hazánk keleti térségében egyes helyeken még népes állományai élnek (BÁLINT 1996).

A védett területen belül a tenyészésre alkalmasnak tünö élöhelyfoltok esetében csak egyetlen egyben fordul elő. Hernyójának tápnövénye, a Rumex acetosella itt tömegesen nő. Az imágók rajzási ideje május végétől június közepéig tart.

A Maculinea nausithous és a Maculinea teleius európai elterjedési területének határán helyezkedik el Magyarország. Így hazánkban csak a két faj szegélypopulációi élnek. A hazai nedves vérfüves kaszálórétek visszaszorulásával, mely a hagyományos állattartási formák, müvelési ágak folyamatos csökkenésének következménye, e két faj élöhelyei is jelentösen lecsökkentek.

A Maculinea nausithous elterjedési területe kelet felé Balatonföldvár Bélavár közötti képzeletbeli összekötő vonaltól nyugatra található. Ezeken a területeken a két faj tipikus élőhelyén együtt fordul elő. A Maculinea teleius populációk a Dunántúli-dombságon, keleti irányban egyre szórványosabbá válnak, de ez a tenyészésre alkalmas élöhelyek számának a csökkenésével mutat korrelációt.

A Látrányi Puszta Természetvédelmi Területen mindkét fajnak erös populációja él, amelyek évek óta stabilnak tünnek.

A fajok fejlődésük során speciális és bonyolult myrmecofil kapcsolatokkal rendelkeznek.

A Dráva mentén és Belső-Somogyban szerzett megfigyelések alapján úgy tünik, hogy a Látrányi Puszta Természetvédelmi Területen a fajnak három különböző kezelésü élöhelyen van tenyészöhelye.

1. Évente kétszer kaszált nedves vérfüves rétek. Ezen az élőhelyen a fajok zavartalanul képesek fejlődni. Itt mindkét faj megtalálja magának a peterakáshoz szükséges virágzó vérfüvet, valamint a fejlödéséhez szükséges hangyafajt és a környezeti feltételeket is. Ezek az élőhelyek kétszikű virágokban bővelkednek, amelyek biztosítják az imágók számára a táplálkozási lehetőségeket.

2. Nem kezelt, egykor vérfüves rétek. Ez az élöhelytípus a védett területen belül napjainkban gyorsan terjed. A kezeletlen területeken a Solidago térhódítása következtében az élőhely növényfaj-összetétele, a miliőtényezők és az állatközösségek, amelyek a faj 
fejlödésében is szerepet játszanak, folyamatosan átalakulnak. Ennek következménye, hogy a Maculinea nausithous populációja teljesen, míg a Maculinea teleius populációja drasztikus módon visszaszorult. Kezelésként a leghatékonyabb védelmi intézkedésnek az ilyen az élőhelyfoltokban az aranyvessző (Solidago) virágzás előtti kaszálását tartom.

3. Nem kezelt mocsár- és láprét foltok szegélye. Ezeket az élöhely-foltocskákat feltétlenül el kell különiteni az előzőektöl, ugyanis feltételezhetően ezek lehettek a faj természetes élőhelyei, mert hasonló élőhelyi adottságokkal rendelkeznek, mint a rendszeres kaszált higrofil vérfüves rétek, ami később kedvezett a fajok megtelepedésének és elterjedésének.

Azonban ezen az élőhelyfolton fejlödő példányok nyáron itt nem találnak táplálkozó helyet, ezért az imágók a közepesen nedves homokbucka-szegélyeken aggregálódnak. A homokbuckák egy része jelenleg kezeletlen, a fentiek miatt a fajok populációira nézve ez a hatás még ismeretlen. Hosszabb távon elképzelhetö, hogy kaszálni vagy legeltetni kellene a homokbuckákat. Így nagyobb lenne a virágos kétszikü növények aránya a homoki gyepekben, ezáltal az imágók a peterakáskor több nektárforráshoz juthatnak.

Az Apatura ilia nem tartozik szorosan a védett terület faunájához, hisz a Dunántúlidombságon elsősorban patakmenti, folyómenti füzes élőhelyekhez kötődik. A területen élőhelye a Tetves-patak menti kisebb-nagyobb füzesekben van. Gyér populációja a terület faunáját inkább csak színesíti, de itt sem kezelési, sem egyéb különleges figyelmet nem érdemel.

A Nephis sappho a Dél-Dunántúl területén többfelé elöforduló, hazánkban egyébként többfelé ritkának tartott faj populációi stabilak. A terepi megfigyelések alapján tudjuk, hogy az élőhely-zavarásra kevésbé érzékeny, néha erősen degradált élőhelyeken (aká$\cos$ ) is elöfordul.

Az Euphydryas aurinia a Dél-Dunántúl területén most került elő elöször. Lelöhelye több szempontból is figyelemre méltó. A látrányi populációja a Balaton egykori mocsárés lápvidékének faunáját őrzö maradványpopuláció is lehet. A faj ismert lelőhelyei a Bakonyalja, a Tapolcai-medence és az Örség láprétjein találhatók.

Biológiai szempontból az utóbbi időben vált ismertté, hogy a fajnak két ökológiai típusa létezik: egy nedvesréti és egy szárazréti forma. Az elmúlt évek kutatásai kimutatták, hogy a szárazréti forma terjedöben van (DiETZEL 1997, ÁвRAHÁM 1998), míg a nedvesréti forma erősen visszaszorult. A Látrányi Puszta Természetvédelmi Területen azonban a nedvesréti forma került elö. Ez állatföldrajzi szempontból is rendkivül érdekessé teszi a különböző faunakörzetek találkozásánál fekvő területet.

A faj élőhelyének viselkedésbiológiai kutatása itt a jövőben feltétlenül indokolt ahhoz, hogy a faj egyetlen dél-dunántúli élöhelyén a faj természetvédelmére vonatkozó információkat összegezhessük.

\section{Természetvédelmi szempontból figyelmet érdemlö, nem védett fajok és élöhelyeik}

Az Oligia fasciuncula atlanto-meditterrán elterjedésü faunaelem, a hazai bagolylepke fauna új tagja. FAJCIK (1998) arról számol be, hogy az elmúlt időszakban elterjedési területét kelet felé kiterjesztette. Magyarországot, Szlovákiát és Észtországot kivéve már a többi európai országból elökerült. Az irodalom szerint napközben is aktív, de egyetlen ismert példányát éjszaka lámpázás során fogtam. Élőhelyeként nyílt erdős sztyeppeket jelölik meg, ahol helyenként gyakori is lehet. Rajzási ideje a nyári hónapokra esik, tápnövényét különbözö füfélék képezik.

A Polypogon gryphalis fajnak az elmúlt 15 évben a Dél-Dunántúl területén erősen lecsökkent a népessége, ezt bizonyítja a természetvédelmi felmérések során az egyre gyérülő számban publikált adatsora (ÄBRAHÁm és UHERKOVICH 2001). 
A Diachrysia zosimi legtöbbször a védett Maculinea fajokkal együtt szokott előfordulni a nedves vérfüves réteken. Annak ellenére, hogy nem védett ugyanolyan jó élöhely minősítő szerepet tölt be, mint az említett két nappali lepkefaj. Hernyójának tápnövénye szintén a Sanguisorba officinalis. Populációi az élöhelyek megszünésével (a vérfüves rétek kaszálásának felhagyásával) országszerte erősen visszaszorultak.

A Hadena silenes hazánkban éri el elterjedésének északi határát, az Alföld homoki gyepeinek és a középhegység dolomit rétjeinek ritka karakterfaja. Belső-Somogy kiterjedt homokos vidékén nem él (ÁBRAHẢM és UHERKoviCH 2001). A Dunántúli-dombság szegélye mentén löszgyep foltok közvetítő szerepe segítségével terjeszthette ki elterjedési területét erre maradvány homoklepel foltra. Első somogyi adata Zamárdi környékéröl ismert (RÉZBÁNYAI 1972).

Az Euxoa segnilis is fejezetten homoki lelöhelyekröl ismert faj. Ritkasága összefügg a természetközeli homoki gyepek elterjedésével, ennélfogva Somogyból csupán három lelöhelyről ismert: Darány, Nagybajom és Látrány. A területen a legnépesebb állománya a magas füvü, nem kezelt homoki gyepekben van.

A Sentina roscida, kis méretü medvelepke faj a Dél-Dunántúlon nagyon szórványosan fordul elő. Mesterséges fényforrásokra kevésbẻ reagál, viszont a száraz gyepekben a késő délutáni órákban könnyen felzavarható. A faj legközelebbi ismert lelöhelyei a Bakony dolomit gyepfoltjain vannak (ÁBRAHÁM 1993). Jelenlegi tenyésző állománya a homokpuszta nem kezelt D-i területén található. Valószínüleg két nemzedéke fejlődik ki évente.

A Látrányi Puszta Természetvédelmi Terület figyelmet érdemlő fajai a fokozottan nedvesség vagy a szélsőségesen szárazság által befolyásolt élőhelyekről ismertek.

$\mathrm{Az}$ általános faunakép alapján jellegzetesek a feltöltődési társulásokhoz kötődő fajok: Hepialus humuli, Phragmatoecia casteneae, Euthrix potatoria, Celaena leucostigma, Archanara sparganii, Archanara dissoluta, Sedina buettneri Laelia coenosa. A védett területen nedves rét, mocsár- és láprét foltokban élnek még a következő ritkább fajok: Apamea scolopacina, Ascometria caliginosa, Plusia festucae, Euphia puppilata, Stegania caricaria, és a kicsit vagilisabb, gyakori fajok: Mythimna pudorina, Mythimna impura, Eustrocia uncula.

A víz által erősen befolyásolt élőhely foltok közül a puhafa ligeterdők, erdőszegélyek kiterjedése a területen belül elég kicsi. Így csupán néhány jellegzetes faja került elő ennek az élöhely típusnak: Cerura erminea, Gastropacha populifolia, Pterostoma palpina, Arctolmis l-album, Apatura ilia. Mivel ez az élöhely típus kicsi a területen, igy az itt emlitett fajok is kis populáció nagyságban vannak jelen, ritkák.

Egykoron - II. József katonai felmérés céljából készült térképei szerint - a területen a mai nedves kaszáló rétek helyén égerliget erdők boríthatták, maradványaik ma már jórészt csak az időszakos vízfolyások mentére korlátozódnak. Jellegzetes fajaik azonban ma is meg vannak a területen: Apatele alni, Apatele cuspis, Apatele leporina, Drepana curvatula, Nola chlamitulalis stb.

A természetvédelmi területen az élöhelyek rendkivül mozaikosak. A nagylepkék - bizonyos mobilitásuk ellenére - személyes lámpázással és fénycsapdával párhuzamosan gyüjtött minták alapján a száraz réteken, a homoki gyepekben nagyon jellegzetesen elkülönültek. Ezeken az élöhelyeken lokálisan gyakoribbnak bizonyult a Heliophobus reticulata, Symira nervosa, Calamia tridens, Calyptra thalictri, ritkább a Hadena irregularis, Euxoa segnilis, és az országos viszonylatban valamivel gyakoribb Malocosoma castrensis, amely a Dunántúli-dombság északi szegélyét kivéve hiányzik erröl a területröl. A nappali lepkék közül az Arethusana arethusa és a Scoliotantides orion fajok érdemelnek a Dél-Dunántúlon nagyon lokális elöfordulásuk miatt fokozott figyelmet.

A védett területen a fás vegetáció másodlagosan hiányzik, ezért a ligetes homokpusztai erdők jellegzetes lombfogyasztó fajai is csak kis populáció nagyságban fordulnak elö. 
Ez különösen a fajszámban látszik meg, ugyanis a somogyi erdökben jellegzetes polifág lomberdei fauna fajait csak kis példányszámban sikerült kimutatni.

A kopárterületek erdészeti hasznosításaként értékes, egykoron homoki gyepek által elfoglalt élőhely foltokat erdei fenyővel telepítettek be a Látrányi Puszta Természetvédelmi Területen a védettség kihirdetését megelőzően.

$\mathrm{Az}$ erdei fenyő monokultúrának, száraz mikroklimatikus körülmények között, nagylepke faunája szegényes. A lepkehernyók elsődleges fogyasztók, így az ilyen típusú élöhelyek faunája viszont nagyon karakterisztikus. Fenyőhöz kötődő fajok közül itt él: a Lymantria monacha, a Panolis flammea, a Hylaea fasciaria, a Bupalus piniarius, a Semiothisa liturata, a Thera obeliscata, a Dendrolimus pini és az Hyloicus pinastri.

\section{Köszönetnyilvánítás}

A szerző köszönetét fejezi ki Orsik Mihálynak (Kaposvár) és Paizs Ottónak (Nagybajom), hogy a terepi munkálatok során segítséget nyújtottak.

Külön köszönet illeti a Duna-Dráva Nemzeti Park Igazgatóságot az 1999. évi kutatások anyagi támogatásáért és a KAC-ot (asz.:027866-01/2001) pályázaton elnyert anyagi támogatásért.

\section{Irodalom}

AbafJ-Aigner L, PÁvel J., Uhryk F. 1899: Ordo. Lepidoptera in: A Magyar Birodalom Állatvilága - Fauna Regni Hungariae. Budapest pp 1-82.

ÁBRAHÁM L. 1992: Boronka-mclléki Tájvédclmi Körzet nagylepkc faunájának tcrmészetvédelmi feltárása I. (Lcpidoptera) - Dunántúli Dolg. Term. Tud. Sor. 7:241-271.

ÁвRAнÁM L. 1993: A Tési-fennsík nagylepkefaunájáról (Lepidoptera) - Folia Musei Historico-Naturalis Bakonyiensis 12: 145-172.

ÁBRAHÁM L. 1998: A nagylepkefauna vizsgálata a Déli-Bakony és a Bakonyalja határvidékén (Lepidoptera) Folia Musei Historico-Naturalis Bakonyiensis 17: 119-140.

ÁBRAHÁm L., UHERKovich Á. 1986: Dudar környćkének nagylepkcfaunája (Lepidoptera) - Folia Musei Historico-Naturalis Bakonyiensis 5: 57-79.

ÁbrahÁm L., UHERKovich Á. 2001: Somogy nagylepke faunájának katalógusa (Lepidoptera: Macrolepidoptera) - Natura Somogyiensis 1: 329-374.

BÁLINT Zs. 1996: A Kárpát-medence nappali lepkći 1. - Budapest pp. 1-183.

DiETZEL Gy. 1997: A Bakony nappali lepkéi - A Bakony természettudományi kutatásának eredményei 21: 1-199.

FAJCIK J. 1998: Die Schmetterlinge Mitteleuropas II Band Bestimmung - Verbreiterung - Flugstandort Bionomic Noctuidae - Bratislava pp. 3-169.

Karsholt, O., Razowski, J. 1996: The Lepidoptera of Europe. A Ditributional Checklist. - Appollo Book, Stenstrup.

KovÁCS L VARGA Z. 1969: A servey of the taxa related Apamea monoglypha Hufn., with the description og a new species (Lepidoptera: Noctuidae) - Acta zool acad. sci Hung. 15: 49-61.

RÉZBÁNYAI L. 1972: Vizsgálatok a Balaton délkeleti (Balatonszabadi-Zamárdi) partvidékének nagylepkefaunáján (Lcp.) - Folia cnt. hung. 25: 229-252.

RonKAY L. 1997: Lepkék. In: Forró L. \& Korsós Z. (eds): Nemzeti Biodiverzitás-monitorozó Rendszer VII. KTM Budapest pp. 1-77.

VARGA Z. 1964: Magyarország állatföldrajzi beosztása a nagylepkefauna komponensei alapján - Folia ent. hung. 16: 1-62.

VARGA Z. 1990: Lepkék (Lepidoptera) rendjc. In: Rakonczay Z. (ed.): Vörös könyv, p. 188-244.

VOJNITS A. 1980: Araszolólepkék I. - Geometridac I. - Magyarország Állatvilága XVI. kötet 14: 1-157. 


\section{Investigation on the butterfly and larger moth fauna of the Látrányi Puszta Nature Conservation Area (Lepidoptera)}

\section{LEVENTE ÁBRAHÁM}

The significant species of the Látrányi Puszta Nature Conservation Area occur in rather wet or extremely dry habitats. The following species live in wet meadows and marshes of the protected area: Hepialus humuli, Phragmatoecia casteneae, Euthrix potatoria, Celaena leucostigma, Archanara sparganii, Archanara dissoluta, Sedina buettneri Laelia coenosa.

Soft wood cover only a small portion of the area therefore only a few significant species of this kind can be found here: Cerura erminea, Gastropacha populifolia, Pterostoma palpina, Arctolmis l-album, Apatura ilia.

It is most probable that wet meadows of today were previously used to be covered by alder woodlands. Nowadays, remains of these forests can only be found along temporary water flows but species typical of this habitat still occur in the area: Apatele alni, Apatele cuspis, Apatele leporina, Drepana curvatula, Nola chlamitulalis.

The butterfly and larger moth fauna of the dry open sandy grasslands shows special characteristics. In these habitats Heliophobus reticulate, Symira nervosa, Calamia tridens, Calyptra thalictri are common while Hadena irregularis, Euxoa segnilis are rare species. Among the butterflies, Arethusana arethusa and Scoliotantides orion are worth mentioning because of their limited occurrence in Southern Transdanubia.

In the protected area the forest vegetation is secondarily missing therefore the species associated with forests only occur in small population. The valuable Scotch pine was introduced on the sandy grasslands as a result of the forestry utilisation of the grasslands Under dry microclimatic circumstances the butterfly and larger moth fauna of the Scotch pine monoculture is rather poor in species. Species living on pine are the following: Lymantria monacha, Panolis flammea, Hylaea fasciaria, Bupalus piniarius, Semiothisa liturata, Thera obeliscata, Dendrolimus pini, Hyloicus pinastri. 